\title{
KESULTANAN PEUREULAK DAN DISKURSUS TITIK NOL PERADABAN ISLAM NUSANTARA
}

\author{
Misri A. Muchsin \\ Universitas Islam Negeri Ar-Raniry \\ Jl. Syeikh Abdul Rauf Darussalam Banda Aceh, 23111 \\ e-mail: misrimuchsin@yahoo.com
}

\begin{abstract}
Peureulak Sultanate and the Discourse on 'Zero Point of Nusantara's Islamic Civilization'. In March 2017, Indonesian Government officially recognized Barus, a historical small city at the western coast of Sumatra, as the zero point of Indonesian Islamic Civilization. This recognition was marked by a relatively modest monument, inaugurated by the President of the Republic of Indonesia. Muslim historians responded differently: some agree and others disagree. The present author finds it very important to underline once again that Peureulak Sultanate at the eastern coast of Aceh was the first sizeable Islamic Kingdom of not just the Indonesia archipelago but also of the whole Southeast Asian archipelago. As a matter of fact, this has been the conclusion of several historical studies. Therefore, from scholarly point of view, the placement of this important monument at Barus needs to be studied and revisited. While Barus was indeed the first point of the arrival of Islam, the Muslim community there did not form any sizeable socio-political force. Peureulak, on the other hand, was successful in doing so.
\end{abstract}

Keywords: Peureulak, Aceh, Nusantara, Southeast Asia, politics, manuscript 


\section{Pendahuluan}

Kedatangan dan pengembangan Islam di Nusantara sampai mencapai hampir ke seluruh Asia Tenggara telah memiliki sejarah yang panjang. Sejarawan Inggris, Thomas W. Arnold menyebutkan bahwa masyarakat di Aceh adalah masyarakat yang mula-mula menerima Islam, sedangkan Peureulak serta Pasai merupakan kerajaan Islam pertama di Nusantara. ${ }^{1}$ Menurut satu keterangan lain, abad pertama Hijriyah atau sekitar abad kedelapan Masehi, Islam sudah datang dan menapaki kawasan ini, tepatnya di Peureulak atau Perlak. Menurut keterangan ahli, Peureulak sebagai satu kerajaan Islam ternama, sudah pernah dipimpin oleh dua puluh orang raja atau sultannya. ${ }^{2}$

Menurut satu kisah, awal Islam di Peureulak sudah mulai sejak masa pemerintahan Khalifah 'Umar Ibn Khaththâb. Ketika itu, Parsi bisa ditaklukan dan rakyatnya diislamkan. Oleh karenanya orang-orang Arab dan Parsi yang sudah berada di Peureulak, ketika itu juga ikut memeluk Islam. ${ }^{3}$ Bahkan ketika terjadi peristiwa peperangan antara pihak 'Ali Ibn Abi Thâlib dengan Mu'âwiyah ibn Abi Shufyân yang terkenal dengan Perang Shiffin, banyak pengikut 'Ali yang disebut sebagai 'Alawiyin melarikan diri dari Tanah Arab ke Asia Tenggara, khususnya ke Peureulak. Terdapat pengikut 'Ali yang melarikan diri ke Nusantara sampai ke negeri Peureulak yaitu 'Ali ibn Muhammad ibn Ja'far Shâdiq ibn Muhammad al-Bâqir ibn Zainal 'Âbidin ibn Husain ibn 'Ali ibn Abi Thâlib."

Kedatangan 'Ali ibn Muhammad ibn Ja'far Shiddiq disambut baik oleh Maharaja Syahir Nuwi dan rakyat Peureulak. Karena ia berasal dari dua keturunan bangsawan terhormat yaitu 'Ali ibn Abi Thâlib dan Fâthimah binti Rasulullah, Maharaja Syahir Nuwi mengawinkan 'Ali ibn Muhammad dengan adik kandungnya, Puteri Makhdum Tansyuri. ${ }^{5}$ Dalam perkawinan bangsawan Quraisy dengan bangsawan Peureulak ini dianugerahkan seorang putera 
yang diberi nama 'Abd al-'Azîz. Setelah itu, 'Abd al-'Aziz dikawinkan pula dengan Puteri Meurah Makhdum Khudawi atau Puteri Peureulak. ${ }^{6}$

Pada tahun $173 \mathrm{H} / 790 \mathrm{M}$ atau pada abad ke I Hijriah bersamaan $8 \mathrm{M}$, dicatat dalam sejarah bahwa Khalifah Harun al-Rasyid, Khalifah Bani 'Abbasiyah mengirim satu armada dakwah berjumlah seratus orang yang terdiri dari bangsa Arab, Parsi (Iran sekarang), dan India ke Bandar Peureulak. Akan tetapi menurut satu riwayat, sebelum tiba di Peureulak, terlebih dahulu sebelumnya singgah di Barus, yang terkenal dengan bandar dagangnya. Rombongan tersebut dipanggil sebagai Nakhoda Khalifah. ${ }^{7}$ Kedatangan Nakhoda Khalifah disambut baik oleh Maharaja Syahir Nuwi. Dari Peureulak inilah Islam bersemi dan selanjutnya berkembang mewujudkan kerajaan Islam di Timur dan Barat Aceh, seperti Pasai, Pedir, Lingga, Daya dan terakhir Aceh Darussalam yang sukses menyatukan kerajaan itu semua di bawah pemimpin besarnya Ali Mughayat Syah (memerintah 1511-1530 M).

Dalam perkembangannya, kerajaan Aceh Darussalam, terutama zaman Sultan Iskandar Muda (1606-1636 M), Sultan Iskandar Tsani dan Sultanah Ratu Safiah al-Din Syah, mengantar kerajaan ini pada puncak kejayaannya. Pimpinan kerajaan yang gemar dan cinta mengembangkan ilmu dan dakwah melalui pengayoman para ulama dan dainya merupakan satu di antara penyebab utama kemajuan kerajaan ini. Mereka yang diayomi Sultan Kerajaan Aceh itu adalah alim-ulama yang mengemban amanah pengembangan ilmu agama.

Artikel ini membahas Peureulak sebagai satu kerajaan Islam ternama dan tertua di Nusantara-Asia Tenggara. Pendekatan yang digunakan adalah pendekatan sejarah dan filologi, dengan memanfaatkan sumber klasik atau naskah yang ada hubungannya dengan tema bahasan, seperti Hikayat Raja Pasai, Sejarah Melayu, 
dan Sulalat al-Salatin karya Tun Seri Lanang. Dari pengkajian akan ditegaskan bahwa Peureulak sebagai satu kerajaan Islam ternama dan tertua di Nusantara-Asia Tenggara, dan sudah pernah dipimpin oleh 20 orang raja atau sultannya. Umumnya ahli yang berpendapat demikian adalah Ali Hasjmy merujuk pada naskah klasik, sebagai catatan dari Abu Ishak al-Makarani, berjudul Risalah Idharul Haq fi Mamlakati Ferla wa al-Fasi, naskah Tazkirat Tabaqat Jumu' Sultan al-Salatin, karya Syekh Syamsul Bahri Abdullah al-Asyi; dan Silsilah Raja-raja Perlak dan Pasai. Studi ini dilakukan untuk mengkaji penetapan Barus sebagai awal titik nol peradaban Islam Nusantara. Harapannya, penetapan tersebut akan dikaji kembali dengan lebih teliti-cermat, sehingga menemukan kepastian historis dan kredibelitasnya.

\section{Kedatangan Islam di Peureulak}

Istilah Peureulak atau Perlak berasal dari nama dari pohon kayu yang digunakan untuk dibuat perahu oleh para nelayan. Orang-orang Aceh menyebutnya sebagai Bak Peureulak. Dalam bahasa Parsi Peureulak disebut sebagai Taj Alam, yang bermakna mahkota alam. ${ }^{8}$ Ada sumber menyebutkan bahwa Islam sebelum didakwahkan di Peureulak mula-mula datang-menapak di Barus (satu wilayah yang pernah menjadi wilayah kekuasaan Aceh), ${ }^{9}$ kemudian baru ke Peureulak. Hal ini seperti beberapa keterangan sumber Hikayat Raja Pasai dan Sejarah Melayu menguatkan hal itu:

36 (44) Setelah berapa lamanya kemudian daripada sabda Nabi SAW. itu, maka terdengarlah kepada segala isi negeri Mekkah nama negeri Samudera. Maka Syarif Makkah pun menyuruh sebuah kapal membawa segala perkakas kerajaan, seraya disuruhnya singgah ke negeri Ma'abri. Adapun nama nakhoda kapal itu Syekh Ismail namanya. Maka kapal itu pun berlayarlah, lalu ia singgah di negeri Ma’abri. Maka kapal Syeih Ismail itu pun berlabuh di laut. 
37 (44-45) Berapa lamanya di laut maka sampailah kapal kepada sebuah negeri, Fansuri namanya. Maka segala orang isi negeri Fansuri itu pun masuklah Islam...Berapa lamanya maka sampai kepada sebuah negeri pula Thobri (Lamri) namanya. Maka orang Thobri itu pun masuk Islam... Berapa lamanya maka sampailah ke negeri Haru namanya. Maka segala orang dalam negeri Haru itu pun masuk Islam... Maka fakir itu pun bertanya orang dalam negeri itu "Di mana negeri yang bernama negeri Samudera?" Maka kata orang Haru itu "Sudah lalu”. Maka fakir itu pun naik ke kapal lalu berlayar pula. Maka jatuh ke negeri Perlak. Maka mereka itu pun diislamkannya. Maka kapal itu pun berlayar ke Samudera. ${ }^{10}$

Keterangan di atas mungkin menjadi argumentasi awal penetapan Barus sebagai awal titik nol peradaban Islam di Nusantara yang ditetapkan beberapa waktu lalu oleh Presiden Republik Indonesia, Ir.Joko Widodo. ${ }^{11}$ Hanya saja perlu dinyatakan, Barus tidak pernah menjadi kerajaan Islam, apalagi menjadi satu kekuatan politik Islam, dan yang pernah menjadi dan berwujud kerajaan Islam awal adalah Peureulak, Pasai dan selanjutnya Aceh Darussalam. Proses pencarian Samudera, untuk mewujudkan perintah seperti yang dimaksudkan sabda Nabi Muhammad SAW., menjadi tujuan utama dan mereka singgah di beberapa tempat seperti tersebut di atas, menjadi wujud Islam di sana, termasuk di Peureulak. Untuk maksud tersebut pada pertengahan abad ke-8 M, Syarif Mekah di zaman khalifah Harun al-Rasyid, bertitah dan menyiapkan sebuah kapal dari Jeddah yang dinakhodai oleh Syekh Ismail beserta Fakir Muhammad (Bekas Raja di Malabar) untuk menyiarkan Islam di Samudera. Kapal dimaksud mula-mula singgah di FansuriBarus. Syeikh Ismail dan rombongan turun ke darat beberapa saat, menemukan beberapa orang untuk diislamkan di sana serta meminta sekaligus mengajar mereka untuk membaca al-Qur'an, kemudian baru meneruskan perjalanan-pelayarannya mencari Samudera, tetapi mereka singgah dahulu di bandar Peureulak. ${ }^{12}$ 
Dengan demikian jelaslah bahwa memang ada kemungkinan pengislaman pertama berlangsung di Fansuri-Barus, dan wilayah ini pernah menjadi wilayah teritorial kesultanan Aceh Darussalam di kemudian hari. Hal ini sangat beralasan, seperti diungkapkan oleh T. Ibrahim Alfian, ${ }^{13}$ karena secara geografis wilayahnya yang strategis, yang terletak antara lautan Hindia dan Laut Cina Selatan yang menghubungkan negeri-negeri sebelah timur, seperti Cina dan Jepang; dan dengan negeri-negeri sebelah barat, yaitu Anak Benua India, Parsi/Persia dan negara-negara Arab, Afrika, serta dengan benua Eropa. Barus merupakan kawasan yang paling ujung barat Sumatera, para pendatang-pedagang dari timur dan barat tentu menjadikan pelabuhan Barus tempat singgah dan perdagangan-rempah-rempah termasuk kapur Barus demikian terkenal. Kawasan ini menjadi tempat bagi para pedagang menunggu giliran datang angin musim timur-laut dan barat-daya yang akan membawa mereka dan barang-barang dagangannya ke tempat tujuan masing-masing, termasuk ke Peureulak.

\section{Peureulak: Kekuatan Pertama Politik Islam di Nusantara}

Kontroversi awal masuk Islam dan sekaligus kerajaan/kesultanan Islam pertama di Nusantara, telah memacu ahli untuk melakukan seminar berulang kali. Di Medan pada 17-20 Maret 1963, di Banda Aceh pada 10-16 Juli 1978, di Rantau Kuala Simpang Aceh Timur ketika itu, pada tanggal 25-30 September 1980, dan seminar khusus tentang Peureulak, dalam rangka milad ke-30 Fakultas Adab IAIN Ar-Raniry pada 30 Oktober 2010. Hasil dan keputusan seminar di Rantau Kuala Simpang Aceh Timur, menetapkan Peureulak sebagai kesultanan Islam pertama di NusantaraAsia Tenggara, dan untuk kenangan bagi generasi mendatang telah membangun Monumen Islam Asia Tenggara (MONISA), dan dengan dukungan semua pihak termasuk pemerintah Aceh Timur ketika itu. Akan tetapi sesuai dengan bergulirnya waktu, 
monumen itu pun seperti ditelan masa, padahal benar-benar menjadi tonggak sejarah, sumber informasi, sumber inspirasi dan destinasi pariwisata Aceh berdimensi sejarah-budaya yang menarik. ${ }^{14}$

Walaupun ada kontroversi, menurut keterangan ahli, Peureulak sebagai satu kerajaan Islam ternama, tertua dan sudah pernah dipimpin oleh 20 atau paling tidak ada yang katakan 19 orang raja atau sultannya. ${ }^{15}$ Adapun ahli yang berpendapat demikian di antaranya adalah Ali Hasjmy yang merujuk pada naskah klasik sebagai catatan dari Abu Ishak al-Makarani yang berjudul

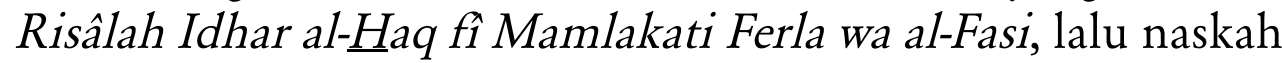
Tazkirat Tabaqat Jumu' Sultan al-Salatin karya Syeikh Syamsul Bahri Abdullah al-Asyi, dan Silsilah Raja-raja Perlak dan Pasai. Dari naskah-naskah ini disimpulkan bahwa Kerajaan atau Kesultanan Peureulak sebagai kerajaan Islam pertama di Nusantara yang diproklamirkan pada 1 Muharram $225 \mathrm{H} / 840 \mathrm{M}$, dengan sultan pertamanya Sultan Alauddin Sayyid Maulana Abdil Aziz Syah. Kesultanan Peureulak berakhir pada tahun $1292 \mathrm{M} .{ }^{16} \mathrm{Hal}$ ini sesuai dengan disatukannya ke kerajaan Pasai di Samudera Gedong, Aceh Utara sekarang.

Menurut catatan sejarah, bahwa hubungan perdagangan antara Arab, Parsi, Cina, Eropa dan lain-lain dengan Nusantara sudah berjalan sejak sebelum kedatangan Islam. M. Arifin Amin mengutip Maharaja Onggang Parlindungan, pengarang buku Tuanku Raoyang menyebutkan sebelum lahir Nabi Muhammad SAW. bahkan sebelum lahir 'Isa a.s, orang-orang Parsi (sebelum Islam) telah mengadakan hubungan perdagangan lewat jalan laut dengan Tiongkok. ${ }^{17}$ Dalam pada itu sebahagian pedagang Arab dan Parsi telah membina perkampungan di rantau Asia, di antaranya dengan Peureulak. Hal dimaksud seperti catatan seorang peneliti Balitbang Kementrian Agama RI, sebagai berikut: 
Untuk tempat persinggahan kapal mereka mendirikan Rendezvous (tempat bertemu di tepi pantai) di Bombay India dan di Perlak Aceh. Ketika itu Perlak adalah sebuah kerajaan yang masyhur di kalangan saudagar-saudagar Arab-Parsi karena letak pelabuhannya yang strategik. Yang menjadi Raja Perlak ketika itu ialah Maharaja Syahir Nuwi yang berdarah Parsi campuran Siam. ${ }^{18}$

Pada masa pemerintahan Khalifah 'Umar Ibn Khaththâb 13-24 H/634644 M, Parsi dapat ditaklukkan dan rakyatnya diislamkan. Sebab itu, orang-orang Arab dan Parsi yang berada di Peureulak ketika itu ikut juga memeluk Islam. ${ }^{19}$ Bahkan ketika terjadi peristiwa peperangan antara 'Ali Ibn Abi Thâlib dengan $\mathrm{Mu}^{\text {'awiyah }}$ ibn Abi Shufyan yang terkenal dengan Perang Shiffin, banyak pengikut 'Ali yang disebut sebagai 'Alawiyin melarikan diri dari Tanah Arab. Terdapat pengikut 'Ali yang melarikan diri ke Nusantara sampai ke negeri Peureulak yaitu 'Ali ibn Muhammad ibn Ja'far Shiddiq ibn Muhammad al-Baqir ibn Zainal 'Abidin ibn Husein ibn 'Ali ibn Abi Thâlib. ${ }^{20}$

Kedatangan keturunan 'Ali ini disambut baik oleh Maharaja Syahir Nuwi dan rakyat Peureulak, karena ia berasal dari dua keturunan bangsawan terhormat yaitu 'Ali ibn Abi Thâlib dan Fâthimah binti Rasulullah. Oleh karenanya, Maharaja Syahir Nuwi menikahkan 'Ali ibn Muhammad dengan adik kandungnya Puteri Makhdum Tansyuri. ${ }^{21}$

Dalam perkawinan bangsawan Quraisy dengan bangsawan Peureulak ini dianugerahkan seorang putera yang diberi nama 'Abdul 'Aziz. Setelah itu, 'Abdul 'Aziz dikawinkan pula dengan Puteri Meurah (bangsawan pribumi) Makhdum Khudawi atau Puteri Peureulak. ${ }^{22}$

Pada tahun $173 \mathrm{H} / 790 \mathrm{M}$ atau pada abad I H/ $8 \mathrm{M}$, seperti sudah disebutkan di awal artikel ini, dicatat dalam sejarah bahwa Khalifah Harun al-Rasyid, Khalifah Daulah 'Abbasiyah mengirimkan 
satu armada dakwah berjumlah seratus orang yang terdiri dari bangsa Arab, Parsi (Iran sekarang), dan India ke Bandar Peureulak. Rombongan tersebut disebutkan sebagai Nakhoda Khalifah. ${ }^{23}$ Kedatangan Nakhoda Khalifah ini disambut baik oleh Maharaja Syahir Nuwi. Menurut cerita rakyat sekitar, bahwa Bandar Khalifah untuk ibu kota Kesultanan Peureulak diambil dari nama nakhoda Khalifah, yang telah ikut mempopulerkan bandar dan kesultanan ini sebagai pusat niaga/perdagangan internasional. ${ }^{24}$

Kehadiran rombongan dakwah tersebut tentu saja semakin menguatkan Islam dalam kehidupan rakyat Peureulak. Ini merupakan usaha lanjutan dari proses islamisasi rakyat Peureulak yang memang telah dilakukan sejak masa Khalifah 'Umar Ibn Khaththâb. Sebagai hasil dari pengaruh Islam yang cepat dalam masyarakat Perlak, pada hari Selasa, 1 Muharram, tahun 225 H /840 M, Maharaja Perlak memproklamirkan secara resmi bahwa Peureulak sebagai kerajaan Islam yang pertama di Asia Tenggara. ${ }^{25}$ Yang menjadi Raja pertama ditabalkan menantunya yaitu 'Abdul 'Aziz dengan gelaran Sultan 'Alaiddin Mualana 'Abdul 'Aziz Syah. ${ }^{26}$ Pada hari peresmiannya, Bandar Perlak ditukar namanya menjadi Bandar Khalifah ${ }^{27}$ sebagai kenangan dan penghargaan kepada rombongan Nakhoda Khalifah yang telah berperan mengembangkan Islam di Peureulak. Bandar Khalifah begitu terkenal di kalangan para pedagang Arab dan non-Arab sekalipun, karena telah menjadi pelabuhan penting dan tempat persinggahan mereka dalam perjalanan ke Cina atau balik ke Asia Barat. ${ }^{28}$

Seiring ditetapkan sebagai kerajaan Islam yang pertama, akhirnya Peureulak mampu menjadi pusat perdagangan Islam di Nusantara. Sesungguhnya, Peureulak telah mencapai kemajuan sejak pertengahan abad ke $9 \mathrm{M}$, dimana Perlak merupakan kawasan termaju dibandingkan dengan daerah-daerah lain di Sumatera. Hal ini dibuktikan oleh Marco Polo, dimana ia pernah menegaskan bahwa "Perlak selalu didatangi oleh saudagar-saudagar Muslim 
yang membawa penduduk Bandar ini memeluk undang-undang Muhammad yang terkenal kemudian dengan sunnah Rasulullah dan syariat Islam." ${ }^{29}$

Pada masa Sultan 'Abdul 'Aziz Syah (840-864 M), sistem pemerintahan kerajaan Perlak telah tersusun dengan rapi. Menurut sejarah ia bercirikan organisasi kerajaan 'Abbasiyah. Para Sultan Perlak sangat ambil berat dalam bidang pendidikan. Ini dibuktikan dengan didirikan sebuah institusi pendidikan Islam Zawiyah Buket Cibrek ${ }^{30}$ yang diresmikan pada tahun $865 \mathrm{M} .{ }^{31}$ Menurut sejarah ia merupakan lembaga pendidikan Islam tertua di Asia Tenggara. Kejayaan ini dicapai pada masa pemerintahan Sultan 'Alaiddin Maulana 'Abdur Rahim Syah yang memerintah dari (864-888 M), Sultan kedua kerajaan Islam Perlak. Pada masa pemerintahan Sultan Sayyid Maulana `Abbas Syah yang memerintah dari tahun 888-913 M, Sultan ke III Perlak, dicatat satu lagi kegemilangan dengan didirikan lembaga pendidikan kedua iaitu Zawiyah Cot Kala Perlak yang diresmikan pada tahun $899 \mathrm{M} .{ }^{32}$ Dalam bidang pendidikan, dengan lembaganya yang sudah eksis ketika itu, menjadi "kiblat pendidikan Islam Nusantara," karena lembaga inilah yang telah banyak menghasilkan alumni dan kemudian mereka berperan sebagai pendidik dan sekaligus mubaligh Nusantara yang berjasa dalam penyebaran dan Islamisasi Asia Tenggara umumnya dan Nusantara khususnya.

Dari aspek pertanian, Perlak merupakan daerah penghasil lada dan rotan. Dalam bidang industri, Perlak menjadi daerah penghasil emas yang banyak terdapat di Alue Meuh atau sungai Emas. Dalam bidang seni rakyat, Perlak menghasilkan ukiran seni yang indah seperti gading gajah dan kayu yang meraih simpatik dari para pedagang asing. Seluruh aspek ini telah menjadi faktor pendorong bagi kemajuan Perlak. 


\section{Kemunduran Kesultanan Peureulak}

Ada beberapa faktor mengapa Kesultanan Peureulak mengalami kemunduran. Pertama, pertentangan aliran Syiah dan Sunni. ${ }^{33}$ Pada akhir pemerintahan Sultan ke III, Sultan 'Alaiddin Maulana Sayyid 'Abbas Syah, kerajaan atau kesultanan Peureulak mulai timbul persengketaan. Peristiwa ini menyebabkan popularitas Peureulak sedikit menurun. Awalnya, ketika pulangnya salah seorang keluarga Meurah ${ }^{34}$ Peureulak dari Mekah yaitu Meurah 'Abdul Kadir Syah. Ia merupakan tokoh yang bermazhab Syâfi'i dan berpaham Sunni. Oleh karena itu, timbul persengketaan antara kedua paham, Sunni dan Syiah, yang sudah lama memerintah Peureulak. ${ }^{35}$ Peristiwa ini terus berlanjut sampai pada masa pemerintahan Sultan Sayyid Maulana 'Ali Mughayat Syah. Untuk mengatasi masalah ini, daerah Perlak mau tidak mau harus dibagi menjadi dua daerah. ${ }^{36}$ Pertama, Perlak bahagian Baroh (Utara) yang berada dalam kekuasaan Sayyid Maulana dengan ibukotanya Bandar Khalifah. Kedua, Perlak bahagian Tunong (Selatan) yang berada di bawah kepemimpinan Makhdum Meurah 'Abdul Kadir Syah dan pusat pemerintahannya berada di Bandar Tualang.

Pada ketika itu, kerajaan Islam Peureulak telah dibagi menjadi Utara dan Selatan atau yang disebut juga sebagai Peureulak Daratan dan Peureulak Pesisir yang diperintah oleh dua Dinasti, masing-masing Dinasti 'Aziziyah ${ }^{37}$ dan Dinasti Makhdum yang diasaskan oleh Meurah 'Abdul Kadir Syah. Pada masa pemerintahan Makhdum 'Abdul Malik Syah Johan Berdaulat dari 966-973 M, Sultan Perlak ke VII, sekali lagi terjadi huru-hara. Tetapi ia mampu menyelesaikan huru hara ini dengan suatu perjanjian damai yang disebut Perjanjian Alue Meuh, pada 10 Muharram 353 H/963 M. Ada empat isi dari perjanjian ini. ${ }^{38}$ Pertama, kedua belah pihak tidak boleh angkat senjata. Kedua, Dinasti 'Aziziyah memerintah Perlak Baroh. Ketiga, Dinasti Makhdum memerintah Perlak Tunong. Keempat, hubungan luar negeri harus di bawah satu 
pimpinan, dalam hal ini diserahkan kepada Sultan 'Abdul Malik Syah. Akibat perjanjian ini, Peureulak dapat diselamatkan dari perpecahan dan kehancuran.

Faktor kedua penyebab kemunduran kerajaan ini adalah adanya serangan Kerajaan Sriwijaya. Penyerangan Sriwijaya ke Peureulak karena Sultan Peureulak menolak permintaan Sriwijaya agar kerajaan Peureulak tunduk di bawah kekuasaannya dan membayar upeti. Tim Sejarah Aceh Timur mengutip isi surat penolakan tersebut dari kitab Idhar al-Haq fi Mamlakatil Peureulak karangan Abu Ishak al-Makarany al-Pasy. Butiran surat tersebut seperti berikut:

Paduka Tuan Sriwijaya, Telah maklum adanya surat Paduka Tuan, sayang kami tidak dapat kabulkan permintaan Paduka Tuan. Tidak sah hukumnya kami orang Islam harus tunduk kepada agama Budha, bila perang diperlukan kami menanti.

Sulthan Alaidin Sayid Maulana Mahmud Syah (Kerajaan Negeri Peureulak, 10 Muharram 375 H. $=985$ M. $)^{39}$

Kemakmuran negeri Peureulak membuat Maharaja kerajaan Sriwijaya di Palembang Sumatera Selatan menyerangnya pada tahun $375 \mathrm{H} / 988 \mathrm{M},{ }^{40}$ ditambah lagi karena iri hati Sriwijaya atas perkembangan Islam di Peureulak dengan begitu cepat. Pada hari Ahad bulan Zulhijjah 377 H., Sultan 'Alaiddin Sayyid Maulana Mahmud Syah di Peureulak Baroh meninggal dunia akibat serangan tersebut. Dengan itu kerajaan Peureulak dikuasai sepenuhnya oleh Sultan Makhdum Malik Ibrahim Syah Johan Berdaulat di Peureulak Tunong dan terus menentang Sriwijaya. ${ }^{41}$

Ketidakstabilan politik internal, terutama kerajaan yang terpaksa dibagi menjadi Peureulak Tunong dan Peureulak Baroh menjadi salah satu satu faktor penyebab kerajaan Islam Peureulak menjadi demikian lemah. Peperangan dengan Sriwijaya yang berjalan selama tiga tahun menjadi faktor kedua kerajaan Perlak 
mundur. Perang ini berakhir dengan Sriwijaya terpaksa meninggalkan Peureulak dan pulang ke Palembang untuk menghadapi ancaman serangan Dharma Wangsa Raja Mataram dan serangan Indra Cola dari India. Dengan berakhirnya pendudukan Sriwijaya ke atas Peureulak, kerajaan dapat disatukan kembali.

Raja terakhir yang memerintah Peureulak ialah Sultan Makhdum Malik 'Abdul 'Aziz Syah 662-692 H/1263-1292 M. Walaupun masih bertahan tetapi kondisinya semakin lemah. Selanjutnya kerajaan Perlak disatukan menjadi federasi di bawah kerajaan Samudera Pasai di Geudong Aceh Utara pada abad ke 7 H/13 $\mathrm{M}^{42}$ Dengan demikian keberadaan dan kebesaran Peureulak sebagai pusat pemerintahan utama sudah bergeser ke Samudera Pasai di Geudong Aceh Utara.

\section{Penetapan Titik Nol Peradaban Islam Nusantara}

Pada tanggal 24 Maret 2017, Presiden RI, Joko Widodo mengadakan kunjungan kerja ke Kecamatan Barus, Kabupaten Tapanuli Tengah. Atas permintaan masyarakat di sana, Presiden menetapkan dan meresmikan Tugu Titik Nol Islam Nusantara. Menurut Hendri Susanto Tobing (Sekretaris Daerah Kabupaten Tapanuli Tengah), pemerintah daerah menyiapkan kehadiran Presiden Jokowi untuk meresmikan titik nol peradaban penyebaran agama (bukan hanya Islam) di seluruh Indonesia yang dimulai dari Barus. Dijelaskan dan ditetapkan oleh Presiden Jokowi, bahwa sejarah penyebaran agama-agama di Indonesia, terutama Islam, Nasrani, Hindu dan Budha dimulai dari Barus. "Khusus untuk Muslim, sebagai buktinya adalah situs Mahligai dan Situs Papan Tinggi yang menyebarkan Islam kira-kira abad kelima masehi. Diikuti perkembangan selanjutnya yang masuk melalui Timur Tengah melalui Tapanuli Tengah ke seluruh Nusantara." ${ }^{43}$ 
Keterangan dan sekaligus argumentasi penetapan titik nol Islam di Barus, seperti kutipan di atas, ada yang janggal dan malah sesuatu yang mustahil. Misalnya disebutkan penyebaran Islam di sana "kira-kira abad kelima masehi"? Hal ini jelas tidak mungkin atau mustahil, karena Islam mulai didakwahkan oleh Nabi Muhammad SAW di Mekah, sesuai dengan awal diterimanya wahyu pada tahun $611 \mathrm{M}$ atau baru abad ketujuh Masehi. Nabi Muhammad lahir pun tahun $571 \mathrm{M}$ atau abad keenam. Oleh karenanya masuk dan penyebaran Islam di Barus pada abad lima masehi sesuatu yang mengada-ada dan tidak ada data dan fakta sejarah yang mendukungnya.

Menurut satu keterangan, proses masuknya Islam ke Barus khususnya, Sumatera dan Nusantara pada umumnya terkait erat dan diawali dari perjalanan para pedagang Arab yang singgah di Barus. Peristiwa itu sudah dimulai sejak zaman Nabi Muahammad SAW., yaitu orang-pedagang Arab yang pergi berdagang ke CinaTiongkok dan mereka kebanyakan singgah di Bandar Barus terlebih dahulu. Misalnya kisah seorang pedagang Arab yang bernama Wahab bin Abu Kasbah dan rombongannya, ingin berdagang ke Cina dan singgah di pulau Morsala, yang letaknya antara pantai Barus dan Sibolga. Di pulau tersebut Wahab sambil istirahat memperbaiki kapalnya, mengadakan salat berjamaah dan membeli 10 budak yang berasal dari Nias, kemudian dibawa ke Cina guna dididik untuk menjadi ulama, dan di pulau Morsala sendiri ditetapkan seorang kadi yang bernama Saka. Dialah yang berperan mengislamkan penduduk setempat di kemudian hari. Sementara 10 budak yang sudah diislamkan dan dididik hingga menjadi ulama, menjadi penyebar Islam ke berbagai wilayah di kemudian hari. Berkaitan dengan penyebaran Islam di Nusantara, Barus menjadi salah satu salurannya. Ada satu keterangan menarik berkenaan dengan kedatangan Islam di Barus, sesuai dengan penjelasan buku The Religious Life of Chinese 
Muslims, bahwa keberadaan Islam di Barus terkait dengan misi Dinasti Tang di bawah kepemimpinan Kaisar Kao Tsung, yang mengirim misi persahabatan ke Madinah yang ketika itu memerintah Khalifah 'Utsmân bin 'Affân, dan dalam waktu bersamaan mengirim pula misi yang sama ke Cina. Ketika itulah misi dari Madinah dalam perjalanan ke Cina melalui laut, singgah terlebih dahulu di Barus untuk penambahan kebutuhan makanan dan menunggu peralihan angin-musim. Dengan demikian selama berada di Barus utusan Madinah ini diprediksi berdakwah menyebarkan Islam kepada penduduk setempat, sehingga mulailah Islam dikenal di Barus. Malah sumber ini juga menginformasikan bahwa misi dari pemerintah Madinah, dari Barus melanjutkan perjalanannya ke Tulang Bawang, Lampung, pusat pemerintahan Sriwijaya di Palembang, ke Brunei dan baru selanjutnya ke Kanton, Cina.

Keterangan yang menyatakan orang Arab-Madinah menjadikan Barus tempat transit, jika dihubungkan dengan makam-makam yang ada di situs Mahligai dan situs makam Papan Atas atau Tangga Seribu, membuktikan kebenarannya, karena yang dimakamkan di kedua situs makam tersebut umumnya dari Arab, seperti makam Syekh Mahmud yang berada di puncak bukit Tangga Seribu/Papan Atas dengan panjangnya mencapai delapan meter, pada nisannya menginformasikan bahwa almarhum berasal dari Tanah Arab.

Keterangan lain, yaitu dari Kitab Sejarah Melayu, yang menyebutkan bahwa Syekh Ismail yang berasal dari Mekah, khilafahnya di Madinah mau menuju Samudera Pasai, tetapi tidak tahu persis kawasan tujuannya. Ia memilih singgah lebih dahulu di Bandar Barus, dan memperkenalkan Islam kepada masyarakat setempat. Kemudian dari sana baru ia melanjutkan ke Pasai untuk menyebarkan Islam pula di sana. Dari ungkapan terakhir memberi sinyal bahwa Barus merupakan wilayah yang mula-mula menerima dan didatangi Islam. Kemudian baru ke 
wilayah lain, yaitu ke Peureulak dan Pasai. Hanya saja, walaupun Barus yang mula-mula menerima Islam, tetapi umat Islam di sana tidak menghasilkan atau tidak membentuk kekuasaan atau kerajaan Islam sebagai kekuatan politiknya, tetapi masyarakat Islam di Peureulak lah yang sukses mencapai kekuatan politik Islam pertama di Nusantara.

\section{Penutup}

Berdasarkan studi di atas dapat disimpulkan bahwa Peureulak merupakan kerajaan Islam ternama dan tertua di Nusantara bahkan di Asia Tenggara. Kerajaan ini pernah dipimpin oleh 20 orang raja. Kesimpulan ini didukung oleh sejumlah pakar, misalnya Ali Hasjmy, di mana ia merujuk pada naskah klasik seperti Risâlah Idhar al-Haq fi Mamlakati Ferla wa al-Fasi, naskah Tazkirat Tabaqat Jumu' Sultanul Salatin, dan Silsilah Raja-raja Perlak dan Pasai. Dari naskah-naskah tersebut disimpulkan bahwa kerajaan atau kesultanan Peureulak adalah kerajaan Islam pertama di Nusantara yang diproklamirkan pada 1 Muharram $225 \mathrm{H} /$ 840 M, dengan Sultan pertamanya Sultan Alauddin Sayyid Maulana Abdil Aziz Syah. Kesultanan Peureulak berakhir pada tahun 1292 M. Kemudian, kerajaan ini disatukan dengan Kerajaan Pasai di Samudera Gedong Aceh Utara sekarang setelah beberapa waktu mengalami perpecahan dan pasca penyerangan Kerajaan Sriwijaya dari Palembang. Kemudian, tentu saja penetapan Barus sebagai awal titik nol Islam Nusantara perlu dikaji kembali secara lebih mendalam, teliti dan cermat, sehingga bisa ditemukan kepastian historisnya, apalagi memang agama Islam tidak menjadi kekuatan politik di Barus, dan bahwa kawasan ini awalnya merupakan bekas kawasan kekuasaan Kerajaan Aceh di masa itu. 


\section{Pustaka Acuan}

Alfian, Teuku Ibrahim. Wajah Aceh dalam Lintasan Sejarah. Banda Aceh: Pusat Dokumentasi dan Informasi Aceh, 1999.

Ambary, Hasan Muhammad. "Mencari Jejak Kerajaan Islam Tertua di Indonesia (Perlak).” Kertas Seminar Sejarah Masuk dan Berkembangnya Islam di Aceh dan Nusantara, Aceh Timur, 25-30 September 1980.

Amin, M. Arifin et al. "Sejarah Masuk dan Berkembangnya Islam di Aceh”(Kertas Seminar Sejarah Masuknya Islam di Aceh Timur 1972.

Arnold, Thomas W. The Preaching of Islam: A History of the Propagation of Muslim Faith. USA: Kessinger Publishing, 2006.

Bustamam-Ahmad, Kamaruzzaman. "From Power to Cultural Landscapes: Rewriting History of Shi'ah in Aceh," dalam Journal of Indonesian Islam, Vol. 11, No. 2, 2017.

Djamil, M. Yunus. Gerak Kebangkitan Aceh: Kumpulan Karya Sejarah Muhammad Junus Jamil. Bandung: Jaya Mukti, 2005.

Djamil, M. Yunus. Tawarich Raja-raja Keradjaan Atjeh. Banda Aceh: Kodam I Iskandar Muda, 1968.

Fakhriati. "Peradaban Islam di Peureulak dalam Perspektif Kajian Filologis.” Makalah, Fakultas Adab IAIN Ar-Raniry, 30 Oktober 2010.

Hasjmy, A. Syi'ah dan Ahlusunnah Saling Rebut Pengaruh di Kepulauan Nusantara. Surabaya: t.p., 1993.

Hasjmy, A. "Sejarah Pemerintahan Selama Berdiri KerajaanKerajaan Islam di Aceh." KertasSeminar Masuk dan Berkembangnya Islam di Aceh, Banda Aceh, Juli 1978.

Hasjmy, A. Sejarah Masuk dan Berkembangnya Islam di Indonesia. Bandung: Al-Ma'arif, 1993. 
Hasjmy, Ali, et al., "Sejarah Kerajaan Islam Perlak." Kertas Seminar Sejarah Masuk dan Berkembangnya Islam di Aceh dan Nusantara di Aceh Timur 25-30 September 1980.

Hasjmy, Ali. "Sejarah Pemerintahan Selama Berdiri KerajaanKerajaan Islam di Aceh.” Kertas Seminar Masuk dan Berkembangnya Islam di Aceh, Banda Aceh, Juli 1978.

Hasjmy, Ali. Kebudayaan Aceh dalam Sejarah. Jakarta: Beuna, 1983.

Ishak, Abdullah. Islam di Nusantara (Khususnya di Tanah Melayu). Kuala Lumpur: Badan Dakwah dan Kebajikan Malaysia, 1990.

Jakobi, Tgk. A.K. Aceh dalam Perang Mempertahankan Proklamasi Kemerdekaan 1945-1949 dan Peranan Teuku Hamid Azwar sebagai Pejuang. Jakarta: Gramedia Pustaka Utama kerjasama dengan Yayasan Seulawah RI-001, 1998.

Lambourn, Elizabeth. "The Formation of the Batu Aceh Tradition in Fifteenth-century Samudera-Pasai," dalam Indonesia and The Malay World, Vol. 32, 2004.

Lanang, Tun Seri. Sulalat al-Salatin, terj. Muhammad Haji Salleh. Kuala Lumpur: Yayasan Karyawan \& DBP, 1997.

Majalah Santunan, Tahun IV, No. 49, Banda Aceh, November 1980.

Team Sejarah Aceh Timur. "Masuknya Islam di Peureulak A. Timur dan Perkembangannya." Kertas Seminar Sejarah Masuk dan Berkembangnya Islam di Aceh dan Nusantara di Aceh Timur 25-30 September 1980.

Zainuddin, M. Tarikh Aceh dan Nusantara. Medan: Pustaka Iskandar Muda, 1961. 


\section{Catatan Akhir:}

${ }^{1}$ Thomas W. Arnold, The Preaching of Islam: A History of the Propagation of Muslim Faith (USA: Kessinger Publishing, 2006).

${ }^{2}$ Mereka adalah yang pertama Sultan 'Alauddin Sayyid Maulana 'Abdul 'Aziz Syah (225-249 H/840-865 M); dan terakhir Sultan Makhdum 'Alauddin Malik 'Abdul Aziz Syah Johan Berdaulat (662-692 H/1263-1291 M).

${ }^{3}$ Ali Hasjmy, "Sejarah Pemerintahan Selama Berdiri Kerajaan-Kerajaan Islam di Aceh,” (Kertas Seminar Masuk dan Berkembangnya Islam di Aceh, Banda Aceh, Juli 1978), h. 5.

${ }^{4}$ Ibid., h. 18.

${ }^{5}$ Team Sejarah Aceh Timur, "Masuknya Islam di Peureulak A. Timur dan Perkembangannya," (Kertas Seminar Sejarah Masuk dan Berkembangnya Islam di Aceh dan Nusantara di Aceh Timur 25-30 September 1980), h. 5.

${ }^{6}$ Majalah Santunan, Tahun IV, No. 49, Banda Aceh, November 1980, h. 12.

${ }^{7}$ Ali Hasjmy et al., Sejarah Kerajaan Islam Perlak, (1980), h. 4. Lihat juga, Abdullah Ishak, Islam di Nusantara (Khususnya di Tanah Melayu) (Kuala Lumpur: Badan Dakwah dan Kebajikan Malaysia, 1990), h. 89.

${ }^{8}$ Hasan Muhammad Ambary, "Mencari Jejak Kerajaan Islam Tertua di Indonesia (Perlak)" (Kertas Seminar Sejarah Masuk dan Berkembangnya Islam di Aceh dan Nusantara, Aceh Timur, 25-30 September 1980), h. 6; Ali Hasjmy et al., "Sejarah Kerajaan Islam Perlak" (Kertas Seminar Sejarah Masuk dan Berkembangnya Islam di Aceh dan Nusantara di Aceh Timur 25-30 September 1980), h. 8.

${ }^{9}$ Penjelasan buku The Religious Life of Chinese Muslims. Keterangan lain, yaitu dari Kitab Sejarah Melayu, yang menyebutkan bahwa Syekh Ismail yang berasal dari Mekah, khilafahnya di Madinah mau menuju Samudera Pasai, tetapi tidak tahu persis kawasan tujuannya. Ia memilih singgah lebih dahulu di Bandar Barus, dan memperkenalkan Islam kepada masyarakat setempat. Kemudian dari sana baru ia melanjutkan ke Pasai untuk menyebarkan Islam pula di sana. Dari ungkapan terakhir memberi sinyal bahwa Barus merupakan wilayah yang mula-mula menerima dan didatangi Islam. Kemudian baru ke wilayah lain, yaitu ke Peureulak dan Pasai.

${ }^{10}$ Tun Seri Lanang, Sulalat al-Salatin, terj. Muhammad Haji Salleh (Kuala Lumpur: Yayasan Karyawan \& DBP, 1997), h. 44-45.

11"Barus, Titik Nol Islam Nusantara," dalam Kompas, 18 Oktober 2018.

${ }^{12}$ Abdullah Munchi menjelaskannya dalam Sejarah Melayu, seperti dikutip oleh M. Zainuddin, Tarikh Aceh dan Nusantara (Medan: Pustaka Iskandar Muda, 1961), h. 120.

${ }^{13}$ Teuku Ibrahim Alfian, Wajah Aceh dalam Lintasan Sejarah (Banda Aceh: Pusat Dokumentasi dan Informasi Aceh, 1999), h. 1.

${ }^{14}$ Majalah Santunan, Tahun IV, No. 49, Banda Aceh, November 1980, h. 12.

${ }^{15}$ Lihat Ali Hasjmy, Kebudayaan Aceh dalam Sejarah (Jakarta: Beuna, 1983), h. 45-47. 
${ }^{16}$ Fakhriati, "Peradaban Islam di Peureulak dalam Perspektif Kajian Filologis" (Makalah, Fakultas Adab IAIN Ar-Raniry, 30 Oktober 2010), h.3.

${ }^{17}$ M. Arifin Amin et al., "Sejarah Masuk dan Berkembangnya Islam di Aceh" (Kertas Seminar Sejarah Masuknya Islam di Aceh Timur 1972), h. 12.

${ }^{18}$ Ali Hasjmy, "Sejarah Pemerintahan Selama Berdiri Kerajaan-Kerajaan Islam di Aceh” (Kertas Seminar Masuk dan Berkembangnya Islam di Aceh, Banda Aceh, Juli 1978), h. 5.

${ }^{19}$ Ibid., h. 5.

${ }^{20}$ Ibid., h. 18.

${ }^{21}$ Team Sejarah Aceh Timur, "Masuknya Islam di Peureulak A. Timur dan Perkembangannya," h. 5.

${ }^{22}$ Ibid., h. 6.

${ }^{23}$ Abdullah Ishak, Islam di Nusantara (Khususnya di Tanah Melayu) (Kuala Lumpur: Badan Dakwah dan Kebajikan Malaysia, 1990), h. 89.

${ }^{24}$ Fakhriati, "Peradaban Islam di Peureulak," h.2.

${ }^{25} \mathrm{Tgk}$. A.K. Jakobi, Aceh dalam Perang Mempertahankan Proklamasi Kemerdekaan 1945-1949 dan Peranan Teuku Hamid Azwar sebagai Pejuang (Jakarta: Gramedia Pustaka Utama kerjasama dengan Yayasan Seulawah RI-001, 1998), h. 17-18.

${ }^{26}$ M. Yunus Djamil, Tawarich Raja-raja Keradjaan Atjeh (Banda Aceh: Kodam I Iskandar Muda, 1968), h. 5; M. Yunus Djamil, Gerak Kebangkitan Aceh: Kumpulan Karya Sejarah Muhammad Junus Jamil (Bandung: Jaya Mukti, 2005), h. 12.

${ }^{27}$ Bandar Khalifah terletak di Aceh Timur sekitar $5 \mathrm{Km}$ dari Kota Peureulak sekarang ke arah hulu atau pedalamannya.

${ }^{28} \mathrm{~A}$. Hasjmy, Sejarah Masuk dan Berkembangnya Islam di Indonesia (Bandung: Al-Ma'arif, 1993), h. 201.

${ }^{29}$ A. Hasjmy, Sejarah masuk, h. 200.

${ }^{30}$ Buket di sini bermaksud Bukit. Buket Cibrek adalah nama sebuah kampung di Perlak, Aceh Timur.

${ }^{31}$ Amin, Sejarah Masuk dan Berkembangnya Islam di Aceh, h. 22.

${ }^{32}$ Ibid., h. 23.

${ }^{33}$ Tentang Syiah di Aceh, lihat Kamaruzzaman Bustamam-Ahmad, "From Power To Cultural Landscapes: Rewriting History of Shi'ah in Aceh," dalam Journal of Indonesian Islam, Vol. 11, No. 2, 2017.

${ }^{34}$ Meurah berasal dari kata Mohrat bermaksud Maharaja atau Raja-raja. Lihat Ambary, "Mencari Jejak Kerajaan Islam Tertua di Indonesia (Perlak)", h. 7.

${ }^{35}$ A. Hasjmy, Syi'ah dan Ahlusunnah Saling Rebut Pengaruh di Kepulauan Nusantara (Surabaya: t.p., 1993), h. 46.

${ }^{36}$ Ibid., h. 46.

${ }^{37}$ Dinasti Aziziyah adalah era Pemerintahan Sayyid Maulana sebagai pengasas kerajaan Perlak yang memerintah selama 148 tahun bermula 840-988 M. Dinasti Makhdum bermula sejak pemerintahan Makhdum Meurah 'Abdul Kadir Syah atau 
era Pemerintahan Raja-raja pribumi yang memerintah sampai berakhirnya kerajaan Perlak. Lihat, Ambary, "Mencari Jejak Kerajaan Islam Tertua di Indonesia (Perlak)", h. 6 .

${ }^{38}$ A. Hasjmy, Syi áh dan Ahlusunnah, h. 25-26.

${ }^{39}$ Dikutip dari kitab Idhar al-Haq fi Mamlakatil Peureulak karangan Abu Ishak Makarani al-Pasy yang disalin ulang oleh T. Muhammad, 1950, tidak diterbitkan. Lihat, Team Sejarah Aceh Timur, "Masuknya Islam di Peureulak A. Timur dan Perkembangannya," h. 8

${ }^{40}$ Ibid., h. 27.

${ }^{41}$ A. Hasjmy, Sejarah Masuk dan Berkembangnya Islam di Indonesia, h. 200.

${ }^{42}$ Elizabeth Lambourn, "The Formation of the Batu Aceh Tradition in Fifteenthcentury Samudera-Pasai," dalam Indonesia and The Malay World, Vol. 32, 2004.

43“"Inilah Foto dan Sejarah Tugu Titik Nol Islam Nusantara di Barus-Tapteng," dalam https://sumutpos.co/2017/03/24/inilah-foto-dan-sejarah-tugu-titik-nol-islamnusantara-di-barus-tapteng/2. 